\title{
Comparison of oral ampicillin and doxycycline in the treatment of uncomplicated gonorrhoea
}

\author{
WERA ENFORS AND GUNNEL ERIKSSON \\ Department of Dermatology, Södersjukhuset, Stockholm, Sweden
}

It is important to monitor the antibiotic sensitivity of gonococcal strains in vitro and the results of treatment of gonorrhoea. To this end a standard patient record has been elaborated for use as a source document in automatic data processing. After a running-in period of about 3 years, during which a number of changes became necessary, the method has been found to satisfy the medical and data processing requirements set up previously (Eriksson, Persson, and Wessman, 1975) and it has been used in the present study.

Since 1968 oral ampicillin has been used with excellent results in the outpatient department for venereal diseases of the Södersjukhuset, Stockholm, for the treatment of gonorrhoea in both males and females (Eriksson, 1970a, b, 1971a, b, 1973; Eriksson and Wallmark, 1972). After 2 years we decided to see whether the most frequently used dosage (i.e. 2 oral doses of $1 \mathrm{~g}$. ampicillin with a 5-hour interval between them) was still just as effective.

We also thought it of interest to study the results of oral single-dose treatment of uncomplicated gonorrhoea with doxycycline in our geographical area, since highly divergent results have been reported in the literature. Our aim has not been to seek an alternative to ampicillin therapy, as we believe that a penicillin should be the drug of first choice in the treatment of gonorrhoea, but rather to investigate whether oral single-dose treatment with doxycycline constitutes an acceptable form of therapy in cases in which penicillin cannot be given.

In addition, a comparison has been made of treatment with ampicillin and doxycycline in order to find out whether there is any difference between them with regard to the therapeutic results and the incidence of side-effects.

\section{Patients and methods}

The investigation included all patients treated for uncomplicated gonorrhoea in the outpatient department for venereal diseases, Södersjukhuset, Stockholm, during

Received for publication July 17, 1974

Present address: Department of Dermatology, Danderyd Hospital, Stockholm, Sweden a period of one year : from September 6, 1971, to September 5, 1972, with regard to men and from November 1, 1971, to October 31, 1972, with regard to women.

Gonorrhoea was diagnosed by direct microscopy and/or culture. Specimens were collected at all visits : from the urethra in males and from the urethra, cervix, and rectum in females. The prostate gland was palpated in all males; if this was abnormal the case was counted as complicated and excluded from the series. In addition, specimens were collected from women at the first visit for Trichomonas and Candida cultures (Eriksson and Wanger, 1975).

Patients were treated alternately with either $2 \mathrm{~g}$. ampicillin (Doktacillin ${ }^{\circledR}$, Astra Läkemedel AB, Sweden) administered orally in two doses with a 5-hour interval or $0.3 \mathrm{~g}$. doxycycline (Vibramycin ${ }^{\circledR}$, Pfizer AB, Sweden) in a single oral dose with a glass of water. Any patient hypersensitive to penicillin who was next in turn for ampicillin was dropped from the study. Pregnant women coming next in turn for doxyxycline therapy were also excluded. In addition, patients who vomited within a period of 2 hours after taking the drug were also eliminated from the statistical analysis because treatment failures in such cases could be due to inadequate absorption of the drug. If microscopy was positive, treatment was started without awaiting the results of cultures and sensitivity tests.

A positive rectal culture in women was not regarded as a complication, as previously (Eriksson, 1971a), and patients with this were therefore included.

Patients were asked to return for follow-up examinations once a week. In accordance with the Swedish Law against Infectious Diseases, patients infected by gonococcal strains with normal antibiotic sensitivity were recalled for two follow-up examinations, and those affected by less sensitive strains for four. Patients were also questioned regarding side-effects of the drug.

Specimens were cultured on Thayer-Martin medium. In vitro sensitivity tests were performed on all positive cultures for penicillin G, ampicillin, streptomycin, and tetracycline throughout the trial, and for doxycycline from January 1, 1972. Strains for which the MIC was $\geqslant 0.1 \mu \mathrm{g}$. ampicillin per $\mathrm{ml}$. and $>1.0 \mu \mathrm{g}$. tetracycline per $\mathrm{ml}$. respectively were classified as "less sensitive". Strains for which the MIC was $>3 \mu \mathrm{g}$. streptomycin per ml. were classified as resistant.

When treatment was concluded the relevant data was recorded on special forms and processed in the manner described by Eriksson and others (1975). 
The results of treatment were assessed after 10 days. Patients who returned for their first follow-up within 10 days and had a negative culture at this time were entered in the "satisfactory" group and those with a positive culture were assigned to the "treatment failure" group. Only very probable re-infections (intercourse admitted and contact positive) were excluded. The statistical tests employed were the $\chi^{2}$ test with Yates's correction and the exact test by Fisher for small groups.

\section{Results}

During the 1-year study, 1,124 patients (625 males and 499 females) were treated for uncomplicated gonorrhoea.

\section{MALES}

317 males were treated with ampicillin. One vomited within 2 hours of the first dose and was excluded. 307 of the remaining 316 patients returned for follow-up. 263 of these returned within 10 days for the first follow-up; smears and cultures were negative in 259 and positive in four. One of the four positive patients had been re-infected, while three ( $1 \cdot 1$ per cent.) were classified as treatment failures (Table I).

308 males were treated with $0.3 \mathrm{~g}$. doxycycline. Fourteen vomited within 2 hours. All of the remaining 294 returned for follow-up. 237 returned within 10 days; 215 of these were classified as cured, nineteen ( $8 \cdot 1$ per cent.) as treatment failures, and three as re-infections (Table I).

\section{FEMALES}

262 women were treated with ampicillin, and 249 returned for follow-up. 199 returned for the first check within 10 days; of these, 196 were classified as cured, two ( 1.0 per cent.) as failures, and one as a re-infection (Table I).

237 women were treated with doxycycline. Thirteen vomited within 2 hours and were excluded. Of the remaining 224, 219 returned for follow-up. 174 returned for the first follow-up within 10 days, and ten ( 5.7 per cent.) were classed as treatment failures (Table I).

\section{LATE FOLLOW-UP}

196 patients, including men and women, treated with ampicillin or doxycycline returned for their first follow-up later than 10 days after treatment. Three were classified as treatment failures and ten as re-infections; all the others had negative cultures. No patient with a negative culture at the first followup examination had a positive culture at the second.

COMPARISON OF THE RESULTS OF TREATMENT

Ampicillin is thus significantly better than doxycycline both for males $(P<0.001)$ and females $(0.05>P>0.01)$. For both sexes combined the failure rates were $1 \cdot 1$ and $7 \cdot 1$ per cent. respectively $(\mathrm{P}<0.001)$.

\section{GONOCOCCAL SENSITIVITY}

In this investigation $121 / 450$ (26.9 per cent.) of all patients, comprising 79/258 (30.6 per cent.) males and 42/192 (21.9 per cent.) females, were infected by gonococcal strains showing reduced sensitivity in vitro to ampicillin in the ampicillin-treated group (Table II) and $240 / 852(28.2$ per cent.) in the complete series. The treatment failures (three males and two females) were all in the 'less sensitive' group.

$9 / 403(2 \cdot 2$ per cent.) of the patients in the doxycycline group harboured strains with reduced tetracycline sensitivity. Three of the failures were in this group, but the remaining 26 occurred in the sensitive group.

In vitro determinations of sensitivity to doxycycline were carried out in about eighty cases and were similar to the tetracycline sensitivities.

In the doxycycline group $24 / 118$ (20.3 per cent.) of patients infected with $N$. gonorrhoeae less sensitive to ampicillin relapsed but only $5 / 281$ ( 1.8 per cent.) in the sensitive group. This difference is highly significant $\left(\chi^{2}=37 \cdot 76 ; P<0.001\right)$.

Table II shows that $42 / 229$ ( 18.3 per cent.) of the males treated with doxycycline harboured gonococcal strains which were resistant to streptomycin, while the corresponding figure for females was $33 / 173$ (19.1 per cent.) and for the complete series $75 / 402$ (18.7 per cent.). Table II also shows that sixteen out of nineteen of the males who failed to respond to doxycycline were infected by strains resistant to streptomycin. The corresponding figure for females was seven out of ten (Table II). Thus, in all, 23/73 ( 31.5 per cent.) of the patients infected by strepto-

TABLE I Results in those who returned for first follow-up within 10 days after treatment

\begin{tabular}{|c|c|c|c|c|c|c|}
\hline Sex & Drug & $\begin{array}{l}\text { Negative } \\
\text { culture }\end{array}$ & Failure & Re-infection & $\begin{array}{l}\text { Total number } \\
\text { of patients }\end{array}$ & $\begin{array}{l}\text { Difference in } \\
\text { failure rate }\end{array}$ \\
\hline Male & $\begin{array}{l}\text { Ampicillin } \\
\text { Doxycycline }\end{array}$ & $\begin{array}{l}259 \\
215\end{array}$ & $\begin{array}{r}3 \\
19\end{array}$ & $\begin{array}{l}1 \\
3\end{array}$ & $\begin{array}{l}263 \\
237\end{array}$ & $\begin{array}{l}\chi^{2}=12.59 \\
P<0.001\end{array}$ \\
\hline Female & $\begin{array}{l}\text { Ampicillin } \\
\text { Doxycycline }\end{array}$ & $\begin{array}{l}196 \\
164\end{array}$ & $\begin{array}{r}2 \\
10\end{array}$ & $\begin{array}{l}1 \\
0\end{array}$ & $\begin{array}{l}199 \\
174\end{array}$ & $\begin{array}{l}\chi^{2}=5.23 \\
0.05>P>0.01\end{array}$ \\
\hline Total & $\begin{array}{l}\text { Ampicillin } \\
\text { Doxycycline }\end{array}$ & $\begin{array}{l}455 \\
379\end{array}$ & $\begin{array}{r}5 \\
29\end{array}$ & $\begin{array}{l}2 \\
3\end{array}$ & $\begin{array}{l}462 \\
411\end{array}$ & $\begin{array}{l}\chi^{2}=19 \cdot 26 \\
P<0.001\end{array}$ \\
\hline
\end{tabular}


TABLE II Comparison of results of treatment in relation to in vitro sensitivity to penicillin $G$, ampicillin, tetracycline, and streptomycin

\begin{tabular}{|c|c|c|c|c|c|c|c|c|c|c|}
\hline \multirow{2}{*}{$\frac{\text { Treatment }}{\text { Ampicillin }}$} & \multirow{2}{*}{$\frac{\text { Sex }}{\text { Male }}$} & \multirow{3}{*}{$\begin{array}{l}\begin{array}{l}\text { Clinical } \\
\text { result }\end{array} \\
\text { Cure } \\
\text { Failure } \\
\text { Re-infection }\end{array}$} & \multicolumn{8}{|c|}{ Antibiotic and MIC-group ( $\mu \mathrm{g} . / \mathrm{ml})}$. \\
\hline & & & \multicolumn{2}{|c|}{$\begin{array}{l}\text { Penicillin } G \\
<0.1 \geqslant 0.1\end{array}$} & \multicolumn{2}{|c|}{$\begin{array}{l}\text { Ampicillin } \\
<0.1 \geqslant 0.1\end{array}$} & \multicolumn{2}{|c|}{$\begin{array}{l}\text { Tetracycline } \\
\leqq 1.0>1.0\end{array}$} & \multicolumn{2}{|c|}{$\begin{array}{l}\text { Streptomycin } \\
\leqq 3>3^{\mathrm{a}}\end{array}$} \\
\hline & & & $\begin{array}{c}190 \\
1 \\
0\end{array}$ & $\begin{array}{r}64 \\
2 \\
1\end{array}$ & $\begin{array}{r}179 \\
0 \\
0\end{array}$ & $\begin{array}{r}75 \\
3 \\
1\end{array}$ & $\begin{array}{r}247 \\
3 \\
1\end{array}$ & $\begin{array}{l}7 \\
0 \\
0\end{array}$ & $\begin{array}{r}197 \\
1 \\
1\end{array}$ & $\begin{array}{r}57 \\
2 \\
0\end{array}$ \\
\hline & & Total & 191 & 67 & 179 & 79 & 251 & 7 & 199 & 59 \\
\hline & Female & $\begin{array}{l}\text { Cure } \\
\text { Failure } \\
\text { Re-infection }\end{array}$ & $\begin{array}{r}159 \\
0 \\
1\end{array}$ & $\begin{array}{r}31 \\
2 \\
0\end{array}$ & $\begin{array}{r}149 \\
0 \\
1\end{array}$ & $\begin{array}{r}40 \\
2 \\
0\end{array}$ & $\begin{array}{r}182 \\
0 \\
1\end{array}$ & $\begin{array}{l}6 \\
2 \\
0\end{array}$ & $\begin{array}{r}169 \\
0 \\
1\end{array}$ & $\begin{array}{r}21 \\
2 \\
0\end{array}$ \\
\hline & & Total & 160 & 33 & 150 & 42 & 183 & 8 & 170 & 23 \\
\hline \multirow[t]{4}{*}{ Doxycycline } & Male & $\begin{array}{l}\text { Cure } \\
\text { Failure } \\
\text { Re-infection }\end{array}$ & $\begin{array}{r}177 \\
4 \\
2\end{array}$ & $\begin{array}{r}31 \\
15 \\
1\end{array}$ & $\begin{array}{r}161 \\
2 \\
2\end{array}$ & $\begin{array}{r}47 \\
17 \\
1\end{array}$ & $\begin{array}{r}205 \\
18 \\
3\end{array}$ & $\begin{array}{l}3 \\
1 \\
0\end{array}$ & $\begin{array}{r}183 \\
3 \\
1\end{array}$ & $\begin{array}{r}24 \\
16 \\
2\end{array}$ \\
\hline & & Total & 183 & 47 & 165 & 65 & 226 & 4 & 187 & 42 \\
\hline & Female & $\begin{array}{l}\text { Cure } \\
\text { Failure } \\
\text { Re-infection }\end{array}$ & $\begin{array}{r}137 \\
3 \\
0\end{array}$ & $\begin{array}{r}24 \\
7 \\
0\end{array}$ & $\begin{array}{r}115 \\
3 \\
0\end{array}$ & $\begin{array}{r}47 \\
7 \\
0\end{array}$ & $\begin{array}{r}160 \\
8 \\
0\end{array}$ & $\begin{array}{l}3 \\
2 \\
0\end{array}$ & $\begin{array}{r}137 \\
3 \\
0\end{array}$ & $\begin{array}{r}26 \\
7 \\
0\end{array}$ \\
\hline & & Total & 140 & 31 & $\overline{118}$ & $\overline{54}$ & 168 & 5 & $\overline{140}$ & 33 \\
\hline
\end{tabular}

${ }^{a}$ The MIC was $>500 \mu \mathrm{g}$. in nearly all instances. This was the case for all strains among those who failed to respond to treatment.

mycin-resistant strains relapsed, but only $6 / 327$ $(1.8$ per cent.) of those infected by streptomycinsensitive strains. This difference is highly significant $\left(\chi^{2}=73.54 ; P<0.001\right)$. In the ampicillin-treated patients, $82 / 451$ (18.2 per cent.) of the strains were resistant to streptomycin. Four-fifths of the relapses (2/3 males and $2 / 2$ females) were in this group. Again there is a statistically significant difference, though of not such a high degree, between those with streptomycin-resistant and those with streptomycinsensitive strains $\left(\chi^{2}=9.13 ; P<0.01\right)$.

\section{SIDE-EFFECTS}

No serious allergic reactions such as anaphylactic shock or immediate urticaria were noted. More subjective side-effects such as loose stools were reported by 24 patients ( 18 males and 6 females) treated with ampicillin. All of these patients were cured. Nausea was complained of by forty patients (16 males and 24 females) treated with doxycycline, and by two (1 male and 1 female) treated with ampicillin. More objective adverse reactions were rashes and vomiting. The incidence of these reactions is shown in Table III.

\section{Discussion}

In previous reports it has been shown that oral ampicillin administered in two doses of $1 \mathrm{~g}$. with a 5-hour interval, provides effective treatment of uncomplicated gonorrhoea in both men and women, giving a treatment failure rate of only 1.5 per cent. (Eriksson and Wallmark, 1972; Eriksson, 1973).

The present investigation shows that this type of oral ampicillin therapy, with a failure rate of $1 \cdot 1$ per cent., still gives excellent results in the same geographical area 3 years later (Eriksson, 1970a, b, 1971a, b).

The percentage of strains with reduced sensitivity to ampicillin (MIC $\geqslant 0 \cdot 1 \mu \mathrm{g} . / \mathrm{ml}$.) was 16 per cent. in the earlier series (Eriksson and Wallmark, 1972) In this investigation, 26.9 per cent. of the gonococcal strains showed reduced sensitivity to ampicillin in the group treated with ampicillin, and $28 \cdot 2$ per cent. in the entire series. The sensitivity of gonococcal strains to different penicillins will be reported in greater detail in a 2-year study (Eriksson and Wallmark, to be published). Any tendency towards reduced sensitivity to ampicillin, has not as yet had any practical therapeutic consequences.

TABLE III Side-effects

\begin{tabular}{|c|c|c|c|c|c|c|}
\hline \multirow[b]{3}{*}{ Side-effect } & \multicolumn{6}{|c|}{ Treatment } \\
\hline & \multicolumn{3}{|c|}{ Ampicillin } & \multicolumn{3}{|c|}{ Doxycycline } \\
\hline & Males & Females & Total & Males & Females & Total \\
\hline Rash & - & 3 & 3 & - & - & - \\
\hline Vomiting within $2 \mathrm{hrs}$ of administration & 1 & - & 1 & 14 & 13 & 27 \\
\hline Total & 1 & 3 & 4 & 14 & 13 & 27 \\
\hline
\end{tabular}


In the search for a suitable alternative drug for patients allergic to penicillin, we decided to try $0.3 \mathrm{~g}$. doxycycline given in a single dose. Highly variable results have been reported from earlier trials. A failure rate of 4 to 9 per cent. has been reported in men (Lassus, 1968; Moffett, McGill, Masterton, and Schofield, 1972; Petzoldt, 1972; Masterton and Schofield, 1972; Gallai, Sylvestre, and Brault, 1970) and of 2.4 per cent. in a series consisting of both males and females (Lidén, Hammar, Hillström, Wallin, and Öhman, 1971). Others have obtained considerably poorer results, however, with failure rates of 12.7 to 49 per cent. (Gray, Phillips, and Nicol, 1970; Mutchnik, 1972; Baytch and Rankin, 1972; and Jones and Gilleland, 1971). In our study the relapse rate was $8 \cdot 1$ per cent. in males, 5.7 per cent. in females, and $7 \cdot 1$ per cent. overall. Although these results rank among the best reported in the literature, they are still inferior to those obtained with ampicillin, so that we are not inclined to accept doxycycline $0.3 \mathrm{~g}$. in a single oral dose as an entirely suitable form of treatment.

In this study the failure rate was significantly higher in doxycycline-treated patients infected by gonococcal strains showing in vitro resistance to streptomycin than in those with strains sensitive to streptomycin.

Liden and others (1971) stated that three of their six relapsing patients were infected by strains resistant to streptomycin, whereas the overall frequency of such strains was only $12 / 250$ (4.8 per cent.). The low incidence of gonococcal strains showing resistance to streptomycin in vitro could be the reason for their better therapeutic results. It might be possible to utilize the sensitivity of gonococcal strains to streptomycin in vitro as a guide to which patients should be treated with doxycycline in a single dose. Patients with streptomycin-sensitive strains appear to be well suited for such treatment when penicillin cannot be used, but this is not the case in those with streptomycin-resistant strains.

The in vitro sensitivity of gonococcal strains to tetracycline provided little guidance as to the outcome of doxycycline therapy. $2 \cdot 2$ per cent. (9/403) had reduced tetracycline sensitivity when an MIC $>1.0 \mu \mathrm{g} . / \mathrm{ml}$. was taken as the criterion. It is true that three of the relapses occurred in this group, but the remaining 26 relapses were in the fully sensitive group. If the threshold for reduced tetracycline sensitivity were lowered to the same level as that now used for penicillin $\mathrm{G}$ and ampicillin (viz. MIC $\geqslant 0.1 \mu \mathrm{g} . / \mathrm{ml}$.), 96.2 per cent. of the strains in this series would have been rated as 'less sensitive'. Such an alteration of the threshold would not, then, have any practical clinical significance.

Maness and Sparling (1973) found that sensitivities to tetracycline and doxycycline were nearly identical. This was also found to be the case in the present series, but only eighty strains were tested for sensitivity to doxycycline.

Owing to the high incidence of side-effects, the dose of doxycycline used in single-dose therapy cannot be increased.

Even with the dosage employed the incidence of vomiting was 5 per cent. (27/545), and an additional forty patients ( $7 \cdot 3$ per cent.) reported severe nausea.

\section{Summary}

An account is given of a computer-processed 1-year study comprising 1,124 patients (625 males and 499 females) with uncomplicated gonorrhoea. Alternate patients were treated with either two oral doses of $1 \mathrm{~g}$. ampicillin 5 hours apart, or $0 \cdot 3 \mathrm{~g}$. doxycycline in a single oral dose. Ampicillin remained as efficacious as in 1968 to 1970 , in both males and females, in whom the failure rates were $1 \cdot 1$ and 1 per cent. respectively. After doxycycline the failure rate was 8.1 per cent. in males, 5.7 per cent. in females, and 7.1 per cent. overall. Ampicillin was significantly better than doxycycline in the treatment of men $(\mathbf{P}<0.001)$ as well as of women $(0.05>P>0.01)$. 89.7 per cent. $(26 / 29)$ of the relapses in doxycyclinetreated patients occurred in those harbouring strains sensitive to tetracycline. Sensitivity to doxycycline followed the pattern of tetracycline sensitivity. Thus sensitivity tests with these antibiotics provided no practical aid to therapy. The high incidence of nausea and vomiting in patients treated with doxycycline (12 per cent.) makes it inadvisable to increase the dose; instead, multiple doses are necessary to obtain satisfactory results. There were very few adverse reactions to ampicillin; a rash occurred in only three patients $(0.5$ per cent.).

In the group treated with doxycycline, 31.5 per cent. of the patients infected by streptomycinresistant strains relapsed compared with only $1.8 \mathrm{per}$ cent. of patients infected by streptomycin-sensitive strains. This difference is highly significant $(\mathbf{P}<$ 0.001 ). Thus the sensitivity of gonococcal strains to streptomycin in vitro may serve as a valuable guide to the likely outcome of treatment with tetracyclines.

\section{References}

BAYTCH, H., and RANKIN, D. W. (1972) Brit. f. vener. Dis., 48, 129

ERIKsson, G. (1970a) Acta derm.-venereol. (Stockh.), 50, 451

-(1970b) Ibid., 50, 461

- (1971a) Ibid., 51, 305

- (1971b) Ibid., 51, 467

- (1973) Brit. F. vener. Dis., 49, 353

-, Persson, L., and Wessman, J. (1975) Ibid., 51, 104

- and WallmaRK, G. (1972) Acta derm.-venereol. (Stockh.), 52, 419

- 
ERIKsSON, G. and WANGER, L. (1975) 'A one-year study of the frequency of $N$. gonorrhoeae, Trichomonas vaginalis, and Candida albicans in female venereological patients'Brit. $\mathcal{F}$. vener. Dis., 51 (in press)

Gallai, Z., Sylvestre, L., and BRAUlt, J.-P. (1970) Un. méd. Canad., 99, 693

Gray, R. C. F., Phillips, I., and Nicol, C. S. (1970) Brit. F. vener. Dis., 46, 401

JoNes, S. R., and Gilleland, H. E. (1971) HSMHA Hlth Rep., 86, 849

Lassus, A. (1968) Chemotherapy (Basel), 13, 366

LIDÉN, S., HAMMar, H., HILlström, L., WAllin, J., and Öhman, S. (1971) Acta derm.-venereol. (Stockh.), 51, 221

Maness, M. J., and Sparling, P. F. (1973) f. infect. Dis., 128, 321

Masterton, G., and Schofield, C. B. S. (1972) Brit. $\mathcal{F}$. vener. Dis., 48, 121

Moffett, M., McGill, M. I., Masterton, G., and SCHOFIELD, C. B. S. (1972) Ibid., 48, 126

Mutchnick, M. G. (1972) Ibid., 48, 381

Petzoldt, D. (1972) Ibid., 48, 514

Comparaison de l'ampicilline orale avec la doxycycline dans le traitement de la gonococcie non compliquée

SOMMAIRE

Il est rendu compte d'une étude d'un an selon une méthode mathématique concernant 1.124 malades (625 hommes et 499 femmes) atteints de gonococcie non compliquée. Un malade sur deux fut traité soit par 2 doses buccales de $1 \mathrm{~g}$ d'ampicilline à 5 heures d'intervalle, soit par $0,3 \mathrm{~g}$ de doxycycline en une seule dose orale. L'ampicilline resta aussi efficace qu'en 1968-70, aussi bien chez la femme que chez l'homme et les taux d'échec furent respectivement de 1,1 pour cent et de 1,0 pour cent. Avec la doxycycline, le taux d'échec fut de 8,1 pour cent chez les hommes et de 5,7 pour cent chez les femmes, soit 7,1 pour cent au total. L'ampicilline fut significativement meilleure que la doxycycline pour le traitement des hommes $(P<0,001)$ aussi bien que des femmes $(0,05>$ $P>0,01)$. On observa 89,7 pour cent de rechutes chez les malades traités par la doxycycline lorsqu'ils étaient infectés par des souches sensibles à la tétracycline. La sensibilité à la doxycycline fut du même type que la sensibilité à la tétracycline. Ainsi, les épreuves de sensibilité avec ces antibiotiques n'apportent pas d'aide pratique au traitement. L'incidence élevée de nausées et de vomissements chez les malades traités par la doxycycline (12 pour cent) empêche de conseiller une augmentation de la dose; au lieu de cela, des doses multiples sont nécessaires pour obtenir des résultats satisfaisants. Il y eut très peu de réactions à l'ampicilline; une éruption fut seulement observée chez 3 malades ( 0,5 pour cent).

Dans le groupe traité par la doxycycline 31,5 des malades infectés par des souches streptomycinorésistantes rechutèrent contre seulement 1,8 pour cent des malades infectés par des souches streptomycino-sensibles. La différence est hautement significative $(P<0,001)$ ainsi, la sensibilité in vitro des souches à la streptomycine peut être un guide valable pour apprécier les chances de résultat du traitement par les tétracyclines. 